\title{
Historical Perspective of Kshara Sutra
}

\author{
Nidhin Mohan ${ }^{1}$, Ajay Kumar Gupta ${ }^{2}$ \\ ${ }^{1}$ P.G Scholar, Third Year, P.G. Dept. of Shalya Tantra, Rishikul Campus, Uttarakhand Ayurved University, \\ Haridwar (Uttarakhand), India \\ ${ }^{2}$ Professor \& Head of the Department, P.G. Dept. of Shalya Tantra, Rishikul Campus, Uttarakhand Ayurved \\ University, Haridwar (Uttarakhand), India \\ Corresponding Author: Nidhin Mohan
}

\begin{abstract}
Kshara sutra is one of the para surgical procedures in Ayurveda and it has been proven as an effective and first choice of treatment in the management of Fistula-in-ano. The preparation of Kshara sutra has undergone many changes and has passed through various stages before it reached the present standard of scientific manufacturing. Now Kshara sutra is considered as simple, safe and sure treatment modality for Fistula-in-ano
\end{abstract}

Key Words - Kshara sutra, Fistula-in-ano

\section{INTRODUCTION}

Fistula-in-ano is a condition which has been recognised as a difficult surgical disease in all ancient and modern sciences of the world. It has recurrent nature which makes it more and more difficult for treatment. ${ }^{1}$ It has been categorized as a surgical condition and almost all the surgeons starting from Sushruta to Hippocrates, and also down to the modern reputed surgeons of present times have realised the difficult course which this disease offers for its surgical/medical/medico-surgical methods of treatment. Fistula-in-ano is a surgical condition for which maximum modalities of surgical, para-surgical and medical applications have been described. ${ }^{1}$ From historic perspective, there is a widespread notion that the ayurvedic approach to manage Fistula-in-ano is not very different from the Greek system. Although Hippocrates wrote about Anal fistulae and even described different methods of treatment. After Acharya Sushruta, Hippocrates was probably the first describe the use of setons in the management of Anal fistulae. He used horse hair thread that he tightened intermittently around the enclosed muscle. Setons were used in the management of anal fistulae ever since surgeons became aware of the dangerous complications of dividing the entire sphincter complex. John Ardene in his 'Treatise of fistula in ano, Hemorrhoids and others' explain the reason for preferring to cure by ligature than by incision. The technique of the cutting Seton was well known in the seventeenth century, because it was one of the several options presented by Felix, the court barber and surgeon, to king Louis XIV for the treatment of Anal fistula. Felix decided against the thread of cutting seton and opted for surgery. The cure of Louis XIV's Fistula helped to elevate surgery from the barber's domain to its rightful position and eventually led to the creation of Royal academy of surgery. William Allingam, in his book made references to the cutting seton. He described the technique of Mr. Luke who used fine piece of strong twig and screw tourniquet. However, in his later publications he described his personal experiences by 
means of elastic ligatures based on the use in more than 50 patients. Although the cutting has remained in the surgical techniques and has been used over the years by many surgeons, it has never gained widespread acceptance within the surgical community. $^{2}$

The Corpus of Hippocrates described Tent, Lint thread and surgical management for this disease. Hippocrates described the preparation of Lint with already prepared cotton threads moisturized with juice of great Tithymallus. This is roasted and triturated and converted into a tent with the length of fistula tract and thus inserted into the lesion. After the Tent is placed into the tract a ball of the horn is introduced into the rectum which is left there and removed after passing the stools and thus replaced again. On the sixth day it is removed and the Tent is drawn out of the flesh. The ball of raw lint is filled with allum again introduced into the rectum and kept there till it melts totally. Later the rectum is anointed with myrrah (smoothening ointment) till the parts are united. Sushruta also advised the usage of medicated suppository prepared out of clarified butter and honey processed with Cassia fistula, turmeric and other drug combination. The lint thread mentioned in Greek medicine is quite different from the Kshara sutra mentioned in classical Ayurveda. Hippocrates recommended the use of a slender thread made of raw lint, which is to be folded five times to the length of five inches. Horse hair is wrapped around raw lint to keep the fistula tract patent and to facilitate rethreading. The lint thread is to be directly inserted into the fistula tract with the help of an eye probe. The end of the threads is knotted twice or thrice and the rest of the thread is twisted. The thread is tightened whenever it is loose and the old thread is replaced when it rots. ${ }^{3}$ The process is repeated till the tract is cut completely. It is wrong to completely generalize that the lint thread method and Kshara sutra are essentially the same.
Kshara sutra is a medicated alkaline thread which is well established Para surgical procedure in the management of Fistula-in-ano with a high success rate. This Para surgical procedure was evolved in India and was probably first practised by the Father of Indian surgery, Acharya Sushruta who lived between 800 B.C and 1000 B.C. $\mathrm{He}$ coated the threads with certain medicaments and used them successfully in various Ano-rectal disorders like Fistula, Hemorrhoids and Sinuses. Acharya Charaka has described in the chapter of Shotha chikitsha that Kshara sutra should be used with other measures in the treatment of Bhagandara. $^{4}$ Ashtanga samgraha and Ashtanga hrdaya had clearly mentioned it along with Shastra karma, Agni karma and Kshara karma. It is very important to note that Kshara sutra was specifically indicated by Ashtanga Hrdaya exclusively in Parikshepi type (Horse shoe shape Fistula) of Bhagandara. Acharyas like Charaka, Bhavamisra, Vangasena have quoted the name of Ksharasutra to use in particular diseases without mentioning for the preparation of Kshara sutra. According to Rasa kamadhenu, the thread should be coated with Arka and Snuhi kshira and dried it out. This procedure should be repeated three times, followed by smearing of Kshara but the type of Kshara to be used is not mentioned. ${ }^{5}$ In Chakradatta, Arshodikara chapter clearly mentioned the idea of preparation of Kshara sutra, but the usage of Kshara in the preparation of Kshara sutra has not been mentioned. ${ }^{6}$ Sri Sadananda Sharma in his book 'Rasa Tarangini' has thrown more light on the preparation of Kshara sutra, but not clearly mentioned the usage of Kshara. He emphasized that seven coatings of Haridra powder should be done on thread, layered by Snuhi kshira. He was very specific for its usage in the Gudankuras and Bhagandara. ${ }^{7}$ The preparation of Kshara sutra has undergone many changes and has passed through various stages before it reached the present standard of scientific manufacturing. The standard technique for preparation of 
Kshara sutra was developed in ShalyaShalakya Department of Institute of Medical Sciences, Banaras Hindu University, Varanasi, UP (India) and approved by Indian Council of Medical Research (ICMR). It is prepared by repeated 21 coatings of Snuhi ksheera, Apamarga Kshara and Haridra Choorna. Dr. P.J Deshpande and his associates had done extensive research and had come forward with a scientific and standard method of preparing the Kshara sutra for the management of Fistula in ano. Thorough research was conducted regarding the type of thread to be used, tensile strength of thread, number of coatings, sequence of coating, method of ligation, period of changing Kshara sutra, etc. The Kshara sutra therapy which was developed by him was scientifically proved its effectiveness in multicentric trials and has emerged as a special exclusive curative treatment in the field of Proctology. ${ }^{8}$ This Kshara sutra therapy is capable of dissolving the tough fibrous tissue and ultimately draining it out creating a healthy base for healing. Its gradual and sustained chemical action not only removed the debris from the site of Fistula but it also helps in encouraging fresh healthy granulation there by inducing a long-awaited healing pattern in the depth of tissues. This procedure turned to be a revolutionary technique and is in practice at many Ayurvedic and Modern surgical centres in India and abroad. Later on, various attempts have been made at different centres in India for wider application on Haemorrhoids, Fissure in ano, Pilonidal sinus, Keloids and other conditions. The recurrence and sphincteric loss are two major problems of the Anorectal surgery, which are well addressed by this technique. It not only cures but also eradicates the root cause of the disease, hence the recurrence and the sphincteric loss does not occur. Worldwide, it is getting the recognition and now being identified by WHO as an alternative technique for these disorders. ICMR has also tried it over the Fistula-in-ano patients and found and that it is more advantages than the conventional surgery in its randomized controlled multi centric studies. Kshara sutra therapy of Fistula-in-ano is now well accepted everywhere and has found an honourable place in the text books of Colorectal surgery also, owing to its complication-free curative results.

\section{Acknowledgement: None \\ Conflict of Interest: None \\ Source of Funding: None}

\section{REFERENCES}

1. Kshara sutra therapy in Fistula-in-ano and other Ano-rectal disorders; S.K Sharma, K.R Sharma, Kulwant Singh; Rashtriya Ayurved Vidyapeeth; Pg No-1

2. Recent Advances in Ksara Sutra; Dr. Martha Bhaskar Rao, Dr. G.S Lavekar; Chaukambha publications; Pg No-8

3. Recent Advances in Ksara Sutra; Dr. Martha Bhaskar Rao, Dr. G.S Lavekar; Chaukambha publications; Pg No-9

4. Acharya Charak, Charak Samhita:Vidyotini Hindi Commentary; Edited by Dr. Gorakha Nath Chaturvedi and Pt. Kasinatha Sastri ; Chaukhambha Bharati Academy, Varanasi, Edition: Reprint 2008; Cikitsa Sthaana 12/97, page no.378

5. Recent Advances in Ksara Sutra; Dr. Martha Bhaskar Rao, Dr. G.S Lavekar; Chaukambha publications; Pg No-71

6. Chakradutta,Sri Chakrapanidatt Vaidayaprabha Hindi Commentary by: Dr. Indradeva Tripathi Edition : Reprint, 2012 Arshodhikara-5/148 page no 66

7. Recent Advances in Ksara Sutra; Dr. Martha Bhaskar Rao, Dr. G.S Lavekar; Chaukambha publications; Pg No-12

8. Anal fistula and Kshara sutra treatment; Dr. S.N Pathak; Chaukambha krishnadas academy; Pg No-1

How to cite this article: Mohan N, Gupta AJ. Historical perspective of kshara sutra. Int $J$ Health Sci Res. 2021; 11(5): 216-218. DOI: https://doi.org/10.52403/ijhsr.20210534 